\title{
A new species, Olavius ulrikae (Annelida: Clitellata: Tubificidae), re-assessment of a Western Australian gutless marine worm
}

\author{
Christer Erséus \\ Department of Zoology, Göteborg University, Box 463, SE-405 30 Göteborg, Sweden. \\ Email: christer.erseus $(m$ zool.gu.se
}

\begin{abstract}
Three Western Australian specimens of the gutless marine worm genus Olavius, previously identified as Olavius propinquus Erséus, 1984, are reconsidered and selected as type material of a new species, O. ulrikae sp. nov. This taxon differs from $O$. propinquus $(s, s t r$ ), known only from Fiji in the South Pacific Ocean, by its curved (instead of straight) penial chaetae (in segment $X I$ ), and more numerous somatic chatae in preclitellar segments. Both species belong to an Indo-Pacific complex of closely related forms, the general taxonomy of which is discussed.
\end{abstract}

Keywords: Indian Ocean, morphology, Olavius propinquus, taxonomy

\section{INTRODUCTION}

In a taxonomic account of Western Australian marine Tubificidae, Erséus (1993) recorded 41 species from Rottnest Island and adjacent areas near Perth. One of these species, represented by three specimens from a subtidal locality near Rottnest Island, was identified as Olavius propinquus Erséus, 1984, a gutless tubificid previously known only from Fiji in the South Pacific Ocean. The Western Australian material was described, illustrated and compared to the original $O$. propinquus by Erséus (1993), and the morphological differences noted were considered as intraspecific and associated with the long geographical distance between the two populations. It should be noted that the current knowledge of these small worms in the Indo-Pacific region as a whole is based on limited collection efforts in a few disjunct areas around the Australian continent (Erséus 1981, 1984, 1990, 1993, 1997a, 1997b; Erséus and Bergfeldt 2007).

Recently, while studying several new species of Olavius from the South Pacific, Erséus and Bergfeldt (2007) suggested that the intraspecific morphological variation in gutless Tubificidae is smaller than previously thought. Therefore, specimens from New Caledonia also resembling $O$. propinquas were attributed to a new taxon, $O$. isomerus Erséus and Bergfeldt, 2007, which differs from $O$. propinquus s. str. only in the number of secondary body wall annuli and somatic chaetae. In the light of this, the status of "propinquus" from Rottnest Island was re-assessed, and it is concluded that this form should be regarded as a third species, formally described as new in the present paper.

\section{MATERIAL AND METHODS}

The whole-mounted worms selected as types of O. ulrikae sp. n. (specified below) were already deposited in the Western Australian Museum (WAM), Perth, and the Swedish Museum of Natural History (SMNH), Stockholm. All were originally regarded as non-type specimens of " $O$. propinquus", and information on their collection and preparation was given by Erséus (1993).

\section{SYSTEMATICS}

\section{Family Tubificidae}

\section{Subfamily Phallodrilinae}

Genus Olavius Erséus, 1984

\section{Olavius ulrikae sp. nov.} Figure 1

Olavius propinquus Erséus: Erséus, 1993: 364-365, figure 16 (partim; not Erséus, 1984).

Olavius "propinquus" Erséus: Erséus and Bergfeldt, 2007: 51-52, table 1 (referring to the Western Australian material only).

\section{Material examined}

Holotype'

Australia: Western Australia: E. of Phillip Rock, about $1 \mathrm{~km}$ off Phillip Point (Kingston), Rottnest Island, off Perth, $12 \mathrm{~m}$, fine sand, 19 January 1991, P. Hutchings (WAM V 156-92), whole-mounted specimen; originally identified as Olavius propinquus (see Erséus 1993: 364). 
A B

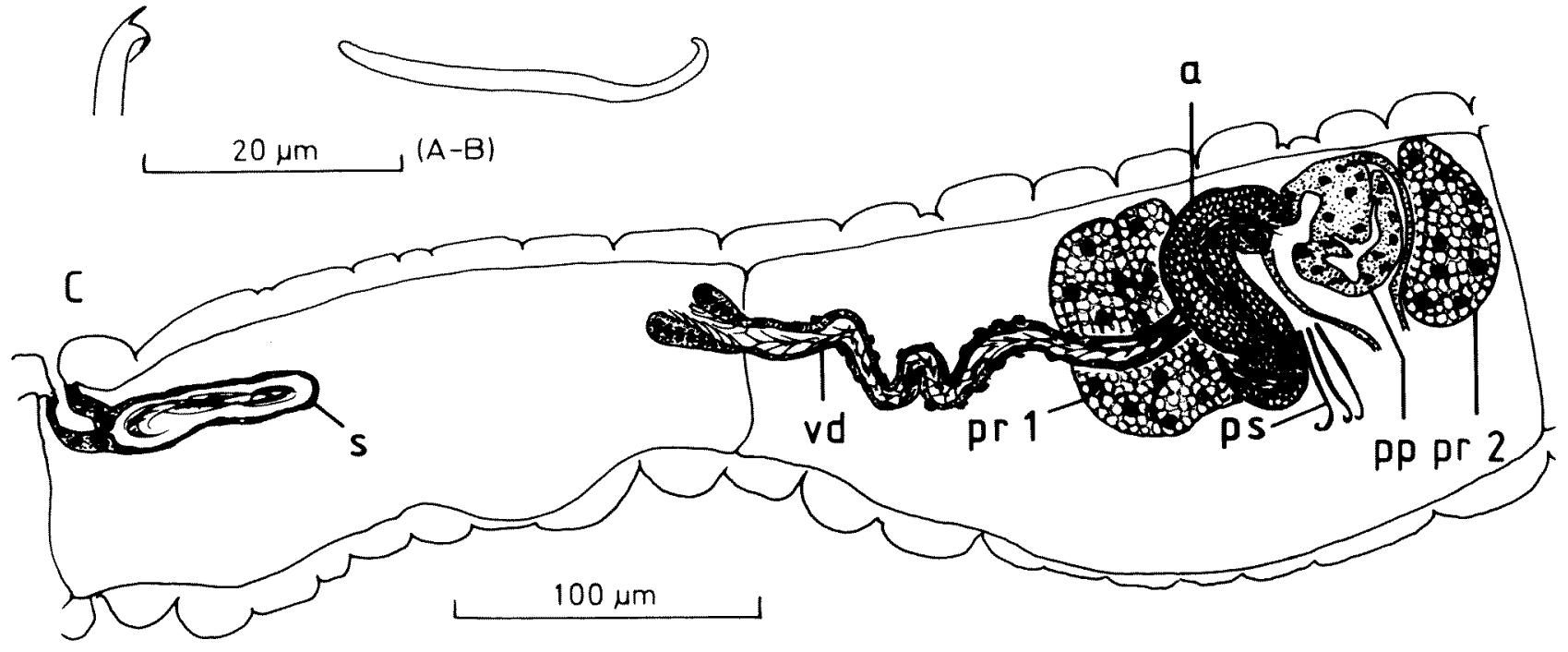

Figure 1 Olavius ulrikae sp. nov. A, somatic chaeta; B, penial chaeta; C, lateral view of spermathecae and male genitalia in segments X-XI (reproduced from Erséus (1993, figure 16)).

\section{Paratypes}

Australia: Western Australia: 2 whole-mounted specimens from type locality, originally identified as $O$. propinquus and lodged in the SMNH Main (non-type) Collection, as ref. nos. 1397 and 29640, respectively (SMNH Type Coll. 6953-6954 (new reg. nos.)); 1 specimen (29640) was first retained in the author's collection (see Erséus 1993: 364) and later deposited in SMNH.

\section{Description (abbreviated, after Erséus (1993))}

Length 7.6-9.2 $\mathrm{mm}, 37-48$ segments. Body slender; maximum width (at XI) $0.15-0.17 \mathrm{~mm}$. Clitellum extending over most of segments $X-X I I$. Secondary annuli (6)7 per (postclitellar) segment. Somatic chaetae (Figure 1A) bifid, 28-42 $\mu \mathrm{m}$ long, 2-3 per bundle anteriorly, 2 per bundle in postclitellar segments. Penial chaetae (Figures 1B; $1 \mathrm{C}$, ps) $28-35 \mu \mathrm{m}$ long, 3 per bundle, with singlepointed, clearly curved outer ends. Male pores in line with ventral somatic chaetae, posteriorly in segment XI. Spermathecal pores in line with dorsal chaetae anteriorly in segment $X$. Alimentary canal absent. Vasa deferentia (Figure 1B, vd) 7-12 $\mu \mathrm{m}$ wide, entering apical ends of cylindrical, curved atria, 80-95 $\mu \mathrm{m}$ long, 19-27 $\mu \mathrm{m}$ wide. Atria (Figure $1 C$, a) opening into inner ends of copulatory sacs, each at base of large papilla (pp). Prostate glands (Figure 1C, pr1 and pr 2) two per atrium. Spermathecae (Figure 1C, s) with short ducts and oblong, thin-walled ampullae, latter 65-80 $\mu \mathrm{m}$ long, 16-23 $\mu \mathrm{m}$ wide.

\section{Etymology}

Named ulrikae, for Mrs Ulrika Lidén (born Bergfeldt), my former Master's student, whose work on South Pacific gutless tubificids drew my attention to the taxonomic status of the present species.

\section{Distribution and habitat}

Known only from Rottnest Island, Western Australia; $12 \mathrm{~m}$, fine sand.

\section{DISCUSSION}

Olavius ulrikae belongs to a homogeneous group of species that all have more or less C-shaped, tubular atria, each of which opens into the inner end of a deep copulatory sac, immediately anterior to the base of a large papilla formed by a large fold of the sac wall (e.g., see Erséus 1981: figure 4; 1984: figure $20 \mathrm{C}$ ). Within this group, $O$. albidus (Jamieson, 1977), O. propinquus Erséus, 1984 (sensu stricto), O. albidoides Erséus, 1997, O. capillus Erséus, 1997, and O. isomerus Erséus and Bergfeldt, 2007, are most similar to O. ulrikae. All six taxa have (1) virtually identical male genital ducts (in $O$. capillus, however, the atrium appears to open at the tip rather than the base of the copulatory papilla; Erséus, 1997), (2) more or less dorsal spermathecal pores, (3) oblong, thin-walled spermathecae, and (4) penial chaetae that are most often three per bundle. However, whereas the penial chaetae of the five previously described species are straight and parallel within the bundle, those of $O$. ulrikae are clearly curved in their outer part (Figure 1B). Moreover, in O. propinquus s. str. and O. capillus, the somatic chaetae are invariably two per bundle throughout the body, while in the others (including O. ulrikae), several bundles in the pre-clitellar part of the worm contain three chaetae. 
Olavius ulrikae, $O$. capillus and $O$. albidoides seem to be restricted to Western Australia. Olavius capillus is known only from the Montebello Islands in the north-western part of the state (Erséus 1997), while O. albidoides (see Erséus 1997) has been recorded also from Rottnest Island (Erséus 1993) and Albany in the south (Erséus 1990). Olavius albidoides is distinguished from $O$. ulrikae as well as the other species mentioned here by its large, characteristically bipartite spermathecal ampullae, and the more lateral position of its spermathecal pores. Interestingly, when first reported from Western Australia (Erséus 1990, 1993), O. albidoides was also taken for a species first described from the South Pacific, i.e., O. albidus, a taxon of the Great Barrier Reef (Jamieson 1977; Erséus 1981, 1997).

Admittedly, the separation of this compex of closely related Olavius species is based on subtle morphological differences, and the taxonomy presented here needs to be tested by molecular data when such are made available. The mitochondrial cytochrome c oxidase subunit 1 (COI) gene has been proposed as a "barcode" marker for identification of animal species (Hebert et al. 2003a; Hebert and Gregory, 2005), and Hebert et al. (2003b) noted that the COI sequences of congeneric species pairs of Annelida available in GenBank differ on average by about $16 \%$. COI works as an identifier for at least some oligochaetes (Erséus and Kvist 2007), and it has revealed cryptic speciation in oligochaetes used as models in biological sciences (reviewed by Erséus and Gustafsson, in press). For the complex of Olavius species treated here, $\mathrm{COI}$ sequences are available only for $O$. albidoides (GenBank AF064037; Nylander et al. 1999), and $O$. albidus (Erséus, unpublished) and they are $16.5 \%$ different. Although scanty, this information may be indicative of the genetic distances to be expected also between other morphologically similar forms of Olavius.

\section{ACKNOWLEDGEMENTS}

I am indebted to the Swedish Research Council (grant $\$$ 621-2004-2397) for financial support, and two anonymous reviewers for valuable comments.

\section{REFERENCES}

Erséus, C. (1981). Taxonomic studies of Phallodrilinae (Oligochaeta, Tubificidae) from the Great Barrier Reef and the Comoro Islands, with descriptions of ten new species and one new genus. Zoologica Soripta 10: 15-31.

Erséus, C. (1984). Taxonomy and phylogeny of the gutless Phallodrilinae (Oligochaeta, Tubificidae), with descriptions of one new genus and twenty-two new species. Zoologica Scripta 13: 239-272.

Erséus, C. (1990). The marine Tubificidae and Naididae
(Oligochaeta) of Southwestern Australia. In F.E. Wells, D.I. Walker, H. Kirkman and R. Lethbridge (eds). The Marine Flora and Fauna of Albany, Western Australia, 1: 43-88. Western Australian Museum, Perth.

Erscus, C. (1993). The marine Tubificidae (Oligochaeta) of Rottnest Island, Western Australia. In F.F. Wells, D.I. Walker, H. Kirkman and R. Lethbridge (eds.), The Marine Flora and Fauna of Rottnest lsland, Western Australia: 331-390. Western Australian Museum, Perth.

Erséus, C. (1997a). Marine Tubificidae (Oligochaeta) from the Montebello and Houtman Abrolhos Islands, Western Australia, with descriptions of twenty-three new species. In F. E. Wells (ed.), The Marine Flora and Fauna of the Houtman Abrolhos Islands, Western Australia: 389-458. Western Australian Museum, Perth.

Erséus, C. (1997b). The marine Tubificidae (Oligochaeta) of Darwin Harbour, Northern Territory, Australia, with descriptions of fifteen new species. In J.R. Hanley, G. Caswell, D. Megirian and H.K. Larsen (eds), Proceedings of the Sixth International Marine Biological Workshop. The Marine Flora and Fauna of Darwin Harbour, Northern Territory, Australia: 99 132. Museums and Art Galleries of the Northern Territory, Darwin, and the Australian Marine Sciences Association

Erséus, C. and Bergfeldt, U. (2007). Six new species of the gutless genus Olavius (Annelida: Clitellata: Tubificidae) from New Caledonia. Zootaxa 1400: $45-58$.

Erséus, C. and Gustafsson, D. (in press). Cryptic speciation in clitellate model organisms. In D. Shain (ed.), Annelids in modern biology. John Wiley \& Sons.

Erséus, C. and Kvist, S. (2007). COI variation in Scandinavian marine species of Tubificoides (Annelida: Clitellata: Tubificidae). Joumal of the Marine Biological Association of the United Kingdom 87: $1121-1126$.

Hebert, P. D. N., Cywinska, A., Ball, S. L. and deWaard, J. R. (2003a). Biological identifications through DNA barcodes. Proceedings of the Roval Society, London $B$ 270: 313-321.

Hebert, P. D. N. and Gregory, T. R. (2005). The promise of DNA barcoding for taxonomy. Systematic Biology 54: $852-859$

Hebert, P. D. N., Penton, E. H., Burns, J. M., Janzen, D. H. and Hallwachs, W. (2004b). Ten species in one: DNA barcoding reveals cryptic species in the neotropical skipper butterfly Astraptes fulgerator Proceedings of the National Academv of Sciences 101 $14812-14817$.

Hebert, P.D.N., Ratnasingham, S and deWard, J.R (2003b). Barcoding animal life: Cytochrome oxidase subunit 1 divergences among dosely related species. Proceedings of the Royal Society, London B 270: 96-99.

Jamieson, B. G. M. (1977). Marine meiobenthic Oligochaeta from Heron and Wistari Reefs (Great Barrier Reef) of the genera Clitellio, Limnodriloides and Phallodrilus (Tubificidae) and Grania 
(Enchytraeidae). Zoological Journal of the Linnean Society 61: 329-349.

Nylander, J. A. A., Erséus, C. and Källersjö, M. (1999). A test of monophyly of the gutless Phallodrilinae (Oligochaeta, Tubificidae) and the use of a $573 \mathrm{bp}$ region of the mitochondrial cytochrome oxidase I gene in analysis of annelid phylogeny. Zoologica Scripta 28: 305-313.

Manuscript accepted 29 August 2007. 